\title{
Effect of dehulled white lupine seeds on the milk production and milk composition in rabbit does and the growth performance of their litters before weaning
}

\author{
L. Uhlířová 1 and Z. Volek \\ Institute of Animal Science, Department of Nutritional Physiology and Animal Product Quality, \\ Prátelství 815, 10400 Prague - Uhř́něves, Czech Republic
}

KEY WORDS: feed intake, lactation, live weight, Lupinus albus, protein sources, rabbits

Received: 1 November 2018

Revised: $\quad 27$ May 2019

Accepted: $\quad 5$ July 2019

${ }^{1}$ Corresponding author:

e-mail: uhlirova.linda@vuzv.cz

\begin{abstract}
The effect of dehulled white lupine seeds (DWLS, cv. Zulika) on milk production and composition in rabbit does and growth performance of their litters before weaning was evaluated. In total, 24 Hyplus rabbit does were allocated into 2 experimental treatments (12 does/treatment; third parturition) and were fed one of the two lactation diets. The litters were standardized to 8 kits after the birth and were offered one of the two weaning diets from days 17 to 32 of age (weaning). Two lactation diets and two weaning diets were formulated to be isonitrogenous and isoenergetic. The control lactation diet (L-SBM) contained $13 \%$ soybean meal (SBM) and $5 \%$ sunflower meal (SFM) as the main crude protein (CP) sources, whereas the experimental lactation diet (L-DWLS) was based on $18 \%$ DWLS. The control weaning diet (W-SBM) contained $7 \%$ SBM as the main CP source, whereas the experimental weaning diet (W-DWLS) was based on 7\% DWLS. No significant differences were detected between treatments regarding performance and milk production in rabbit does during the entire lactation period. Feeding L-DWLS diet increased n-3 polyunsaturated fatty acids content (PUFA n-3; $P<0.001$ ) and PUFA n-3:C20:4n-6 ratio $(P<0.001)$ in milk. In litters of rabbit does fed the L-DWLS diet higher milk intake:solid feed intake ratio $(P=0.024)$ was observed. So, DWLS can be considered as a novel feed component in rabbit diets, without adverse effects on performance of rabbit does and their litters.
\end{abstract}

\section{Introduction}

In intensive livestock production systems, soybean meal (SBM) is the most common protein source. However, the use of SBM has been limited recently due to its high price connected with organic livestock production and chemical treatment during the processing in the oil industry (Musco et al., 2017). It is also an effect of controversies related to the use of genetically modified organisms (Calabró et al., 2015). Therefore, a suitable alternative to
SBM can be lupine seeds which are considered as valuable European-grown protein source for animal nutrition (Chiofalo et al., 2012; Lucas et al., 2015).

Whole white lupine seeds (WLS; Lupinus albus L.) are characterized by relatively high levels of crude protein (CP), oil, non-starch polysaccharides and oligosaccharides (Martínez-Villaluenga et al., 2006; Volek and Marounek, 2009). Common drawback of WLS is the low content of sulphur amino acids (SAA) and also the presence of some antinutritional factors (however present in small 
quantities in recently selected sweet lupine varieties) (Musco et al., 2017).

It was shown that WLS can be considered as the main dietary CP source for rabbits (Volek and Marounek, 2009; 2011; Volek et al., 2014; 2018a; Uhlířová et al., 2015a; 2015b; Gugołek et al., 2017; 2018; Zwoliński et al., 2017), and can completely replace SBM in rabbit diets. Nutritional quality of lupine seeds can be improved by dehulling as observed in broiler chickens (Nalle et al., 2010) and pigs (Flis et al., 1997). On the contrary, in rats Zduńczyk et al. (1996) reported that dehulling of WLS had not positively influenced its nutritional value. Currently, Volek et al. (2018b) conducted a study indicating that dehulled white lupine seeds (DWLS) seem to be a very good CP source for fattening rabbits, as DWLS positively affected feed conversion ratio, meat fatty acid (FA) profile together with related indexes and to some extent meat physical and sensory properties. However, to our knowledge, there is no data in the literature referring the use of DWLS in diets for lactating rabbit does. Therefore, the aim of the present study was to examine the effect of dietary DWLS on milk production and composition in rabbit does and performance of their litters before weaning.

\section{Material and methods}

The present study was approved by the Ethics Committee of the Institute of Animal Science and the Central Commission for Animal Welfare at the Ministry of Agriculture of the Czech Republic and was conducted according to the guidelines for applied nutrition experiments in rabbits (FernándezCarmona et al., 2005).

\section{Diets}

Two lactation diets and two weaning diets were formulated (Table 1). The control lactation diet (L-SBM) contained SBM (130 g/kg as-fed basis) and sunflower meal (SFM; $50 \mathrm{~g} / \mathrm{kg}$ as-fed basis) as the main CP sources, whereas the experimental lactation diet (L-DWLS) was based on DWLS (180 g/ kg asfed basis; cv. Zulika). Similarly, the control weaning diet (W-SBM) contained SBM (70 g/kg as-fed basis) as the main $\mathrm{CP}$ source, whereas the experimental weaning diet (W-DWLS) was based on DWLS (70 g/kg as-fed basis; cv. Zulika). Synthetic amino acids (AA) (L-lysine, DL-methionine and L-threonine) were added to the vitamin-mineral supplement at the expense of premix carrier (wheat flour). All diets were without additional fat. Except of
Table 1. Ingredients and chemical composition of lactation and weaning diets based on soybean meal (L-SBM and W-SBM diet, respectively) or dehulled white lupine seeds (L-DWLS and W-DWLS diet, respectively)

\begin{tabular}{lccccc}
\hline \multirow{2}{*}{ Indices } & \multicolumn{2}{l}{ Lactation diet } & & \multicolumn{2}{l}{ Weaning diet } \\
\cline { 2 - 3 } \cline { 5 - 6 } Ingredients, g/kg as-fed basis & & & & & \\
alfalfa meal & 300 & 300 & 300 & 300 \\
soybean meal & 130 & - & 70 & - \\
sunflower meal & 50 & - & - & - \\
dehulled white lupine seeds & 0 & 180 & - & 70 \\
(cv. Zulika) & & & & \\
wheat bran & 80 & 80 & 330 & 330 \\
sugar beet pulp & 20 & 20 & 70 & 70 \\
oat & 160 & 160 & 155 & 155 \\
barley & 230 & 230 & 45 & 45 \\
vitamin-mineral supplement & 10 & 10 & 9.93 & 8.63 \\
dicalcium phosphate & 7 & 7 & 5 & 5 \\
limestone & 9.5 & 7.5 & 10 & 10 \\
salt & 3 & 3 & 5 & 5 \\
robenidine hydrochloride & - & - & 0.07 & 0.07 \\
L-lysine & - & 1.0 & - & 0.7 \\
DL-methionine & - & 0.5 & - & 0.3 \\
L-threonine & 0.5 & 1.0 & - & 0.3
\end{tabular}

Chemical composition $(n=2), \mathrm{g} / \mathrm{kg}$ as-fed basis

$\begin{array}{lrrrr}\text { dry matter } & 888 & 889 & 880 & 881 \\ \text { crude protein } & 176 & 181 & 164 & 163 \\ \text { NDF } & 313 & 301 & 374 & 375 \\ \text { ADF } & 170 & 163 & 195 & 196 \\ \text { ADL } & 71 & 53 & 45 & 48 \\ \text { ether extract } & 22 & 40 & 33 & 40 \\ \text { starch } & 197 & 207 & 167 & 167 \\ \text { gross energy (GE), MJ/kg } & 17.2 & 17.4 & 16.3 & 16.5 \\ \text { digestible energy }{ }^{2}(\mathrm{DE}), \mathrm{MJ} / \mathrm{kg} & 11.2 & 11.3 & 10.6 & 10.7 \\ \text { lysine } & 8.5 & 7.7 & 7.3 & 6.8 \\ \text { sulphur amino acids } & 5.9 & 5.4 & 5.7 & 5.4 \\ \text { threonine } & 6.6 & 6.3 & 5.2 & 5.3\end{array}$

${ }_{1}$ included per kg of feed: IU: vit. A 12,000, vit. $D_{3} 2,000 ;$ mg: vit. E 50, vit. $K_{3} 2$, vit. $B{ }_{3}$, vit. $B{ }_{2} 7$, vit. $B_{6} 4$, niacinamide 50 , Ca-pantothenate 20 , folic acid 1.7 , biotin 0.2 , vit. $B_{12} 0.02$, choline chloride 600 , Co 1 , Cu 20, Fe 50, I 1.2, Mn 47, Zn 50, Se 0.15; L-lysine, DL-methionine and L-threonine were included in substitution at the premix carrier (wheat flour); ${ }^{2}$ estimated as $0.65 \times$ GE (Xiccato and Trocino, 2010)

AA, the diets had similar $\mathrm{CP}$, neutral detergent fibre (NDF), acid detergent fibre (ADF), starch and energy contents, and met the recommendation of de Blas and Mateos (2010) for intensive rabbit production (Table 1). Both L-SBM and W-SBM diets had slightly more lysine, sulphur amino acids and threonine as compared to the L-DWLS and W-DWLS diets. The L-DWLS and W-DWLS diets were higher in ether extract (EE), due to a generally high EE content of white lupine seeds (Volek and Marounek, 2009).

The FA profile of lactation diets is presented in Table 2. The L-DWLS diet contained less satu- 
Table 2. Fatty acid profile of lactation diets based on soybean meal (L-SBM diet) or dehulled white lupine seeds (L-DWLS diet), \% of total fatty acids $(n=2)$

\begin{tabular}{|c|c|c|}
\hline \multirow{2}{*}{ Indices } & \multicolumn{2}{|c|}{ Lactation diet } \\
\hline & L-SBM & L-DWLS \\
\hline \multicolumn{3}{|l|}{ Saturated fatty acids (SFA) } \\
\hline lauric $(\mathrm{C} 12: 0)$ & 0.08 & 0.06 \\
\hline myristic (C14:0) & 0.27 & 0.32 \\
\hline pentadecanoic (C15:0) & 0.17 & 0.12 \\
\hline palmitic (C16:0) & 16.97 & 14.50 \\
\hline margaric (C17:0) & 0.20 & 0.09 \\
\hline stearic $(\mathrm{C} 18: 0)$ & 3.75 & 2.26 \\
\hline other SFA & 0.72 & 0.82 \\
\hline total SFA & 22.16 & 18.17 \\
\hline \multicolumn{3}{|c|}{ Monounsaturated fatty acids (MUFA) } \\
\hline myristoleic (C14:1) & 0.03 & 0.04 \\
\hline palmitoleic (C16:1) & 0.33 & 0.32 \\
\hline oleic $(C 18: 1 n-9)$ & 19.27 & 34.85 \\
\hline C18:1n-7 & 1.15 & 1.59 \\
\hline eicosenoic (C20:1n-9) & 0.48 & 1.97 \\
\hline other MUFA & 0.18 & 0.09 \\
\hline total MUFA & 21.44 & 38.86 \\
\hline \multicolumn{3}{|l|}{ Polyunsaturated fatty acids (PUFA) } \\
\hline linoleic $(C 18: 2 n-6)$ & 44.85 & 31.13 \\
\hline a-linolenic (C18:3n-3) & 10.61 & 9.65 \\
\hline eicosadienoic (C20:2n-6) & 0.12 & 0.15 \\
\hline eicosatrienoic (C20:3n-6) & 0.01 & 0.04 \\
\hline arachidonic (C20:4n-6) & 0.06 & 0.11 \\
\hline eicosapentaenoic (C20:5n-3) & 0.42 & 0.75 \\
\hline docosatetraenoic (C22:4n-6) & 0.05 & 0.25 \\
\hline clupanodonic (C22:5n-3) & 0.08 & 0.74 \\
\hline docosahexaenoic (C22:6n-3) & - & - \\
\hline other PUFA & 0.20 & 0.15 \\
\hline total PUFA & 56.40 & 42.97 \\
\hline
\end{tabular}

rated fatty acids (SFA) and polyunsaturated fatty acids (PUFA) and more monounsaturated fatty acids (MUFA) than the L-SBM diet. More specifically, the L-DWLS diet contained less palmitic acid (C16:0), margaric acid (C17:0), stearic acid (C18:0), linoleic acid (C18:2n-6) and more C18:1n-9, eicosenoic acid (C20:1n-9), eicosapentaenoic acid (EPA; C20:5n-3), docosatetraenoic acid (C22:4n-6) and clupanodonic acid (C 22:5n-3) in comparison to the L-SBM diet. Diets were offered to rabbits in a form of pellets with a diameter of $3 \mathrm{~mm}$ and a length of $5-10 \mathrm{~mm}$. No antibiotics were included in the feed or in the drinking water. In the case of the weaning diets, the only dietary inclusion was a coccidiostat ( $66 \mathrm{mg}$ of robenidine hydrochloride $/ \mathrm{kg}$ of feed; Alpharma, Antwerp, Belgium).

\section{Animals and experimental design}

The experiment was realized at the experimental rabbit farm at the Institute of Animal Science
(Prague, Czech Republic), which is accredited according to EU standards. Animals were kept under controlled environmental conditions, i.e. room temperature was $15-16{ }^{\circ} \mathrm{C}$, relative humidity was $60 \%$ and lighting regime was $16 \mathrm{~h} /$ day.

In total, 24 Hyplus rabbit does (12 does/treatment) were used for lactation trial evaluating one lactation period (32 days). All does were at the third parturition in order to eliminate the effects of nondietary factors on milk production (Maertens et al., 2006). The does were housed in modified cages $(92 \times 72 \times 45 \mathrm{~cm})$ allowing controlled suckling (once a day at 7:00) and separate access of does and their litters to feed (Fortun-Lamothe et al., 2000; Volek et al., 2014; 2018a). Immediately after the parturition (day 0) does were divided into comparable groups based on their live weigh (on average $4814 \pm 572 \mathrm{~g}$ ), genealogy and balanced interval between second and third kindling, and were fed one of the two lactation diets (L-SBM or L-DWLS) ad libitum for the entire lactation period. The litters were standardized to 8 kits immediately after the birth by cross-fostering.

Feed intake and milk production (as a difference between live weight of does immediately before and after suckling), were recorded daily during the entire lactation period. Rabbit does and litters live weights were recorded weekly. Does were inseminated at day 25 of lactation.

Five does of each group were used to analyse milk composition (dry matter, protein, fat and FA profile). Milk was collected manually by gently massaging the mammary gland at day 21 of lactation; milk ejection was stimulated by administration of 1 IU of oxytocin (NORDIC Pharma, Prague, Czech Republic). Volumes of 25 to $30 \mathrm{ml}$ per doe were obtained from an anterior mammary gland, and this amount was sufficient for the further analyses (Maertens et al., 2006).

Litters (12 litters/treatment) were offered one of the two weaning diets from day 17 of age to weaning (day 32 of age). Litters were fed weaning diet with the same CP source as in the lactation diet of their mothers (litters of mothers fed the L-SBM diet were fed the W-SBM diet and litters of mothers fed the L-DWSL diet were fed the W-DWSL diet). Live weight of litters was recorded weekly from birth to weaning (day 32 of age), litters were weighed before suckling. The solid feed intake of litters was recorded daily from days 17 to 32 of age.

\section{Analytical methods}

AOAC International (2005) procedures were used to determine the dry matter (934.01), CP (954.01), 
EE (920.39), ADF (973.18) and starch (920.40) in diets. Neutral detergent fibre, exclusive of residual ash, was assayed with heat-stable amylase (Mertens, 2002). Acid detergent lignin levels were determined by solubilisation of cellulose with sulphuric acid (Robertson and Van Soest, 1981). Gross energy was determined in an adiabatic calorimeter (C5000 control, IKA-Werke, Staufen, Germany).

Milk samples were analysed for nitrogen (16.036), fat (1.060) and dry matter (16.032) by standard AOAC (1984) procedures.

The FA profile of lactation diets and milk samples was determined following chloroform-methanol extraction of total lipids (Folch et al., 1957). As described by Volek et al. (2014), nonadecanoic acid was used as an internal marker to quantify the FAs in the samples. The isolated methyl esters were analysed using a HP 6890 gas chromatograph (Agilent Technologies, Inc., Santa Clara, CA, USA) with a programmed $60 \mathrm{~m}$ DB-23 capillary column and a flame-ionization detector. Split injections were performed using an Agilent autosampler. Fatty acids were identified by comparing their retention times to those of following standards: PUFA No. 1 Mix, PUFA No. 2 Mix, PUFA No. 3 Mix and 37 Component FAME mix standards (Supelco, Bellefonte, PA, USA).

To determine the AA content, samples of experimental diets were hydrolysed in $6 \mathrm{M}$ hydrochloric acid at $110{ }^{\circ} \mathrm{C}$ for $23 \mathrm{~h}$ and analysed using an Amino Acid Analyzer AAA-400 (INGOS Ltd., Prague, Czech Republic) equipped with an ionexchange column. Cysteine and methionine were ascertained as cysteic acid and methionine sulphone, respectively, after oxidation with performic acid at $5{ }^{\circ} \mathrm{C}$ for $16 \mathrm{~h}$. A post-column derivatization using ninhydrin was used.

\section{Statistical analysis}

Data were processed by one-way analysis of variance using the GLM procedure of SAS (2003) with dietary treatment as the fix effect. Regarding performance of does, milk production and milk composition the individual rabbit was used as the experimental unit, whereas in terms of litter performance the cage represented the experimental unit. The results are presented as means followed by the standard error of mean. All differences were considered to be significant at $P<0.05$.

\section{Results}

No significant differences were detected between dietary treatments in terms of live weight of rabbit does, their feed intake and milk production (Table 3 ). Although non-significantly, it is noteworthy that
Table 3. Milk production and performance of rabbit does fed lactation diets based on soybean meal (L-SBM diet) or dehulled white lupine seeds (L-DWLS diet)

\begin{tabular}{|c|c|c|c|c|}
\hline \multirow{2}{*}{ Indices } & \multicolumn{2}{|c|}{ Lactation diet } & \multirow{2}{*}{ SEM } & \multirow{2}{*}{$P$-value } \\
\hline & L-SBM & L-DWLS & & \\
\hline \multicolumn{5}{|l|}{ Rabbit does live weight, $\mathrm{g}$} \\
\hline after parturition & 4710 & 4919 & 198.7 & 0.467 \\
\hline at weaning (day 32 of lactation) & 4929 & 5257 & 207.2 & 0.281 \\
\hline \multicolumn{5}{|l|}{ Daily feed intake, g/doe } \\
\hline days 2-21 of lactation & 401 & 407 & 14.6 & 0.767 \\
\hline days 22-32 of lactation & 435 & 438 & 13.3 & 0.866 \\
\hline days $2-32$ of lactation & 412 & 418 & 13.6 & 0.798 \\
\hline \multicolumn{5}{|l|}{ Daily milk production, $\mathrm{g}$} \\
\hline days $1-21$ of lactation & 251 & 269 & 11.5 & 0.293 \\
\hline days $22-32$ of lactation & 250 & 269 & 11.8 & 0.255 \\
\hline days $1-32$ of lactation & 251 & 269 & 10.2 & 0.224 \\
\hline
\end{tabular}

SEM - standard error of the mean; $n=12$ rabbit does per treatment

does fed the L-DWLS diet had slightly higher milk production compared to those fed the L-SBM diet during the entire lactation period (Figure 1).

Dry matter, protein and fat contents of rabbit milk did not differ between dietary treatments at day 21 of lactation (Table 4). Milk of does fed

Table 4. Milk composition at $\mathrm{d} 21$ of lactation in rabbit does fed lactation diets based on soybean meal (L-SBM diet) or dehulled white lupine seeds (L-DWLS diet)

\begin{tabular}{lrrrrr}
\hline \multirow{2}{*}{ Indices } & \multicolumn{3}{c}{ Lactation diet } & & \\
\cline { 2 - 5 } & L-SBM & L-DWLS & & \\
\hline Chemical composition, g/100 g & & & & \\
dry matter & 25.05 & 24.95 & 0.684 & 0.982 \\
protein & 9.55 & 9.44 & 0.274 & 0.772 \\
fat & 11.80 & 12.29 & 0.543 & 0.539 \\
Fatty acid profile, \% of total fatty acids & & & \\
caprylic (C8:0) & $26.48^{\mathrm{a}}$ & $24.07^{\mathrm{b}}$ & 0.713 & 0.044 \\
capric (C10:0) & $26.38^{\mathrm{a}}$ & $22.69^{\mathrm{b}}$ & 0.756 & 0.009 \\
lauric (C12:0) & 4.04 & 3.39 & 0.235 & 0.090 \\
myristic (C14:0) & 1.41 & 1.23 & 0.085 & 0.177 \\
palmitic (C16:0) & 10.30 & 10.17 & 0.491 & 0.856 \\
margaric (C17:0) & 0.28 & 0.26 & 0.012 & 0.415 \\
stearic (C18:0) & 2.42 & 2.61 & 0.084 & 0.146 \\
total SFA & $72.01^{\mathrm{a}}$ & $65.50^{\mathrm{b}}$ & 1.011 & 0.002 \\
oleic (C18:1n-9) & $11.32^{\mathrm{b}}$ & $17.62^{\mathrm{a}}$ & 0.479 & $<0.001$ \\
total MUFA & $13.60^{\mathrm{b}}$ & $20.37^{\mathrm{a}}$ & 0.626 & $<0.001$ \\
linoleic (C18:2n-6) & $11.91^{\mathrm{a}}$ & $10.60^{\mathrm{b}}$ & 0.367 & 0.035 \\
a-linolenic (C18:3n-3) & $1.90^{\mathrm{b}}$ & $2.89^{\mathrm{a}}$ & 0.103 & $<0.001$ \\
arachidonic (C20:4n-6) & 0.18 & 0.16 & 0.011 & 0.224 \\
eicosapentaenoic (C20:5n-3) & $0.03^{\mathrm{b}}$ & $0.09^{\mathrm{a}}$ & 0.005 & $<0.001$ \\
total PUFA n-3 & $2.00^{\mathrm{b}}$ & $3.06^{\mathrm{a}}$ & 0.106 & $<0.001$ \\
total PUFA & 14.39 & 14.13 & 0.448 & 0.684 \\
PUFA n-3:C20:4n-6 ratio & $11.13^{\mathrm{b}}$ & $19.08^{\mathrm{a}}$ & 0.524 & $<0.001$ \\
\hline
\end{tabular}

SFA - saturated fatty acids; MUFA - monounsaturated fatty acids; PUFA - polyunsaturated fatty acids; ab - means with different superscripts within a row are significantly different at $P<0.05$; SEM - standard error of the mean; $n=5$ rabbit does per treatment 


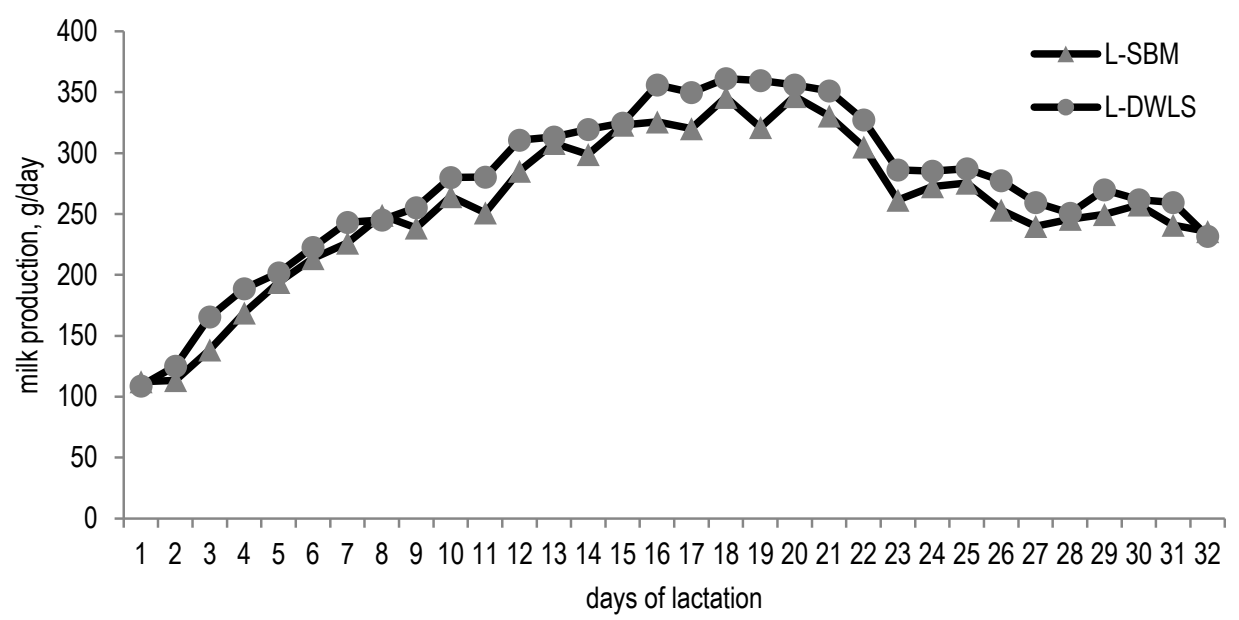

Figure 1. Evaluation of average daily milk production of rabbit does fed lactation diets based on soybean meal (L-SBM diet) or dehulled white lupine seeds (L-DWLS diet)

the L-DWLS diet had lower content of total SFA $(P=0.002)$, with a corresponding decrease of caprylic acid $(P=0.044)$ and capric acid contents $(P=0.009)$. The L-DWLS diet led to higher total MUFA content $(P<0.001)$ with a corresponding increase of C18:1n-9 content $(P<0.001)$. Total PUFA content in rabbit milk was not affected by dietary treatment. The milk of does fed the L-DWLS diet had lower $\mathrm{C} 18: 2 \mathrm{n}-6$ content $(P=0.035)$ and higher $\alpha$-linolenic acid $(\mathrm{C} 18: 3 n-3 ; P<0.001)$ and EPA $(P<0.001)$ contents, and in general a higher content of total PUFA n-3 $(P<0.001)$ than the milk of does

Table 5. Growth performance of litters of rabbit does fed lactation diets containing soybean meal (L-SBM diet) or dehulled white lupine seeds (L-DWLS diet)

\begin{tabular}{|c|c|c|c|c|}
\hline \multirow{2}{*}{ Indices } & \multicolumn{2}{|c|}{ Lactation diet } & \multirow{2}{*}{ SEM } & \multirow{2}{*}{$P$-value } \\
\hline & L-SBM & L-DWLS & & \\
\hline \multicolumn{5}{|l|}{ Live weight of litter ${ }^{1}, \mathrm{~g}$} \\
\hline at birth & 566 & 561 & 14.5 & 0.811 \\
\hline at $d 21$ of age & 3664 & 3841 & 138.5 & 0.381 \\
\hline at weaning (day 32 of age) & 7416 & 7110 & 285.8 & 0.460 \\
\hline \multicolumn{5}{|l|}{ Daily weight gain, g/rabbit } \\
\hline days $1-21$ of age & 18.5 & 20.1 & 0.70 & 0.121 \\
\hline days $22-32$ of age & 42.6 & 40.0 & 1.42 & 0.216 \\
\hline days $1-32$ of age & 26.8 & 26.5 & 0.91 & 0.861 \\
\hline $\begin{array}{l}\text { Daily feed intake }{ }^{2}, \mathrm{~g} / \mathrm{rabbit} \\
\text { days } 17-32 \text { of age }\end{array}$ & 24.2 & 20.8 & 1.33 & 0.086 \\
\hline \multicolumn{5}{|l|}{ Milk efficiency ${ }^{3}$} \\
\hline days $1-21$ of age & 0.59 & 0.51 & 0.046 & 0.267 \\
\hline $\begin{array}{l}\text { Milk intake:solid feed intake } \\
\text { days } 17-32 \text { of age }\end{array}$ & $1.53^{b}$ & $1.97^{a}$ & 0.125 & 0.024 \\
\hline
\end{tabular}

${ }^{1}$ litters were standardized to 8 rabbits on the day of birth; ${ }^{2}$ litters were offered the weaning diet based on soybean meal (W-SBM diet) or dehulled white lupine seeds (W-DWLS diet) ad libitum from day 17 of age; ${ }^{3}$ litter weight gain from day 1 to day 21 of lactation/milk intake; ab - means with different superscripts within a row are significantly different at $P<0.05$; SEM - standard error of the mean; $n=12$ rabbit does per treatment fed the L-SBM diet. There was detected a higher PUFA n-3:arachidonic acid ratio $(P<0.001)$ in milk of does fed the L-DWLS diet (Table 4).

No significant differences between dietary treatments were found regarding live weight of litter, daily weight gain and milk efficiency (Table 5). Daily solid feed intake tended to be lower $(P=0.086)$ in litters of does that were fed the L-DWLS diet and led to the higher $(P=0.024)$ milk intake:solid feed intake ratio compared to litters of does fed the L-SBM diet.

\section{Discussion}

In the present study the $\mathrm{CP}$ source did not affect live weight and feed intake of rabbit does. This finding is in line with previous data in rabbit nutrition (Volek et al., 2014; 2018a; Uhlířová et al., 2015b).

Similarly, the milk production of does was not significantly affected by dietary treatments in this study. The lactation peak, regardless of dietary CP source, coincided with the commonly reported lactation curve of highly productive rabbit does (Maertens et al., 2006). Volek et al. (2014; 2018a) reported similar results of the study comparing a lactation diet based on SBM and SFM with a lactation diets containing WLS or WLS and rapeseed meal (RSM). On the contrary, Uhlírová et al. (2015b) observed significantly higher milk production in rabbit does fed a diet based on WLS during the second lactation period in terms of a longer-term experiment (two consecutive lactation periods) than in those fed a SBM diet. That finding suggests that, for a long period of time, dietary inclusion of WLS might positively affect milk production in rabbit does. However, further research is needed to prove this phenomenon. 
In the present study, milk FA profile clearly reflected FA profile of lactation diets. These results concur with those of other authors (Volek et al., 2014; 2018a; Uhlírová et al., 2015b), who also observed a decrease of SFA content and an increase of MUFA and total PUFA n-3 contents in milk of rabbit does fed a lactation diet based on WLS or on WLS with RSM than in those fed a diet containing traditional CP sources (SBM and SFM).

In our study, we have noted significantly higher milk intake:solid feed intake ratio in litters of does fed the L-DWLS diet than in litters of does fed the L-SBM diet. This finding could be explained by slightly higher milk production of does fed the L-DWLS diet, which means higher availability of milk for their litters, and apparently a lower dependence of litters on the solid feed intake. Uhlírová et al. (2015b) detected a significantly lower solid feed intake in litters of rabbit does fed a lactation diet based on WLS throughout two consecutive lactation periods. Also other studies (Nizza et al., 2002; Di Meo et al., 2003; ArnauBonachera et al., 2017) described that high milk intake during late lactation is related to low feed intake in kits before weaning.

\section{Conclusions}

Results of the present study indicated that feeding of diets containing dehulled white lupine seeds (DWLS) had no adverse effect on live weight, feed intake and milk production in rabbit does or on the performance of litters before weaning. Moreover, dietary inclusion of DWLS increased PUFA n-3 content in milk of rabbit does, and led to the higher milk intake:solid feed intake ratio in their litters. Results of the present study showed that DWLS is an interesting novel feed component, convenient for rabbit nutrition.

\section{Acknowledgements}

The present study was financially supported by the projects NAAR QJ1510136 and MZE-RO0718 provided by the Ministry of Agriculture of the Czech Republic.

\section{References}

AOAC, 1984. Official Methods of Analysis of the Association of Official Analytical Chemists. 14 ${ }^{\text {th }}$ Edition. Arlington, VA (USA)

AOAC International, 2005. Official Methods of Analysis of AOAC International. $18^{\text {th }}$ Edition. Gaithersburg, MD (USA)
Arnau-Bonachera A., Cervera C., Martínez-Paredes E., Ródenas L., Pascual J.J., Blas E., 2017. Milk intake in kits: not only the total amount matters. World Rabbit Sci. 25, 159-166, https:// doi.org/10.4995/wrs.2017.6707

Calabrò S., Cutrignelli M.I., Lo Presti V., Tudisco R., Chiofalo V., Grossi M., Infascelli F., Chiofalo B., 2015. Characterization and effect of year of harvest on the nutritional properties of three varieties of white lupine (Lupinus albus L.). J. Sci. Food Agric. 95, 3127-3136, https://doi.org/10.1002/jsfa.7049

Chiofalo B., Lo Presti V., Chiofalo V., Gresta F., 2012. The productive traits, fatty acid profile and nutritional indices of three lupin (Lupinus spp.) species cultivated in a Mediterranean environment for the livestock. Anim. Feed Sci. Technol. 171, 230-239, https://doi.org/10.1016/j.anifeedsci.2011.11.005

de Blas C., Mateos G.G., 2010. Feed formulation. In: C. de Blas, $J$. Wiseman (Editors). Nutrition of the Rabbit. $2^{\text {nd }}$ Edition. CAB International. Wallingford (UK), pp. 222-232, https://doi. org/10.1079/9781845936693.0222

Di Meo C., Stanco G., Piccolo G., Taranto S., Gazaneo M.P., Nizza A., 2003. Productive performance of rabbits according to preweaning solid feed and milk intake. Ital. J. Anim. Sci. 2, 51-58, https://doi.org/10.4081/ijas.2003.51

Fernández-Carmona J., Blas E., Pascual J.J., Maertens L., Gidenne T., Xiccato G., García J., 2005. Recommendations and guidelines for applied nutrition experiments in rabbits. World Rabbit Sci. 13, 209-228, https://doi.org/10.4995/wrs.2005.516

Flis M., Sobotka W., Zduńczyk Z., 1997. Effect of variety and dehulling on nutritional value of white lupine seeds for growing pigs. J. Anim. Feed Sci. 6, 521-531, https://doi.org/10.22358/ jafs/69563/1997

Folch J., Lees M., Sloane Stanley G.H., 1957. A simple method for the isolation and purification of total lipids from animal tissues. J. Biol. Chem. 226, 497-509

Fortun-Lamothe L., Gidenne T., Lapanouse A., De Dapper J., 2000. Note: An original system to separately control litter and female intake without modification of the mother-young relations. World Rabbit Sci. 8, 177-180, https://doi.org/10.4995/ wrs. 2000.708

Gugołek A., Juśkiewicz J., Strychalski J., Zwoliński C., ŻarySikorska E., Konstantynowicz M., 2017. The effects of rapeseed meal and legume seeds as substitutes for soybean meal on productivity and gastrointestinal function in rabbits. Arch. Anim. Nutr. 71, 311-326, https://doi.org/10.1080/1745 039X.2017.1322796

Gugołek A., Juśkiewicz J., Kowalska D., Zwoliński C., Sobiech P., Strychalski J., 2018. Physiological responses of rabbits fed with diets containing rapeseed meal, white lupine and pea seeds as soybean meal substitutes. Cienc. Agrotec. 42, 297-306, https://doi.org/10.1590/1413-70542018423003318

Lucas M.M., Stoddard F.L., Annicchiarico P., Frías J., MartínezVillaluenga C., Sussmann D., Duranti M., Seger A., Zander P.M., Pueyo J.J., 2015. The future of lupin as a protein crop in Europe. Front. Plant Sci. 6, 705, https://doi. org/10.3389/fpls.2015.00705

Maertens L., Lebas F., Szendrö Zs., 2006. Rabbit milk: a review of quantity, quality and non-dietary affecting factors. World Rabbit Sci. 14, 205-230, https://doi.org/10.4995/wrs.2006.565

Martínez-Villaluenga C., Frías J., Vidal-Valverde C., 2006. Functional lupin seeds (Lupinus albus L. and Lupinus luteus L.) after extraction of a-galactosides. Food Chem. 98, 291-299, https://doi.org/10.1016/j.foodchem.2005.05.074

Mertens D.R., 2002. Gravimetric determination of amylase-treated neutral detergent fiber in feeds with refluxing in breakers or crucibles: collaborative study. J. AOAC Int. 85, 1217-1240 
Musco N., Cutrignelli M.I., Calabrò S., Tudisco R., Infascelli F., Grazioli R., Lo Presti V., Gresta F., Chiofalo B., 2017. Comparison of nutritional and antinutritional traits among different species (Lupinus albus L., Lupinus luteus L., Lupinus angustifolius L.) and varieties of lupin seeds. J. Anim. Physiol. Anim. Nutr. 101, 1227-1241, https://doi.org/10.1111/ jpn.12643

Nalle C.L., Ravindran G., Ravindran V., 2010. Influence of dehulling on the apparent metabolisable energy and ileal amino acid digestibility of grain legumes for broilers. J. Sci. Food. Agric. 90, 1227-1231, https://doi.org/10.1002/jsfa.3953

Nizza A., Stanco G., Di Meo C., Marongiu M.L., Taranto S., Cutrignelli M.I., Juliano L., 2002. Effect of pre-weaning solid feed and milk intake on ceacal content characteristics and performance of rabbits around weaning. Ital. J. Anim. Sci. 1, 95-101, https://doi.org/10.4081/ijas.2002.95

Robertson J.B., Van Soest P.J. 1981. The detergent system of analysis. In: W.P.T. James, O. Theander (Editors). The Analysis of Dietary Fibre in Food. Marcel Dekker. New York, NY (USA), pp. 123-158

SAS (Statistical Analysis System), 2003. SAS/STAT User's Guide (Release 9.2). SAS Institute Inc. Cary, NC (USA)

Uhliřová L., Volek Z., Marounek M., Tůmová E., 2015a. Effect of feed restriction and different crude protein sources on the performance, health status and carcass traits of growing rabbits. World Rabbit Sci. 23, 263-272, https://doi. org/10.4995/wrs.2015.3229

Uhliřová L., Volek Z., Marounek M., Skřivanová V., 2015b. Replacement of soybean meal with white lupin in the nutrition of rabbit does: effect on milk yield, milk composition and growth performance of their litters over two lactation periods. In: J. Capraro, M. Duranti, Ch. Magni, A. Scarafoni (Editors). Developing Lupin Crop into a Major and Sustainable Food and Feed Source. Proceedings of the XIV International Lupin Conference. Milan (Italy), p. 128

Volek Z., Marounek M., 2009. Whole white lupin (Lupinus albus cv. Amiga) seeds as a source of protein for growing-fattening rabbits. Anim. Feed Sci. Technol. 152, 322-329, https://doi. org/10.1016/j.anifeedsci.2009.05.003
VolekZ., Marounek M., 2011. Effect of feeding growing-fattening rabbits a diet supplemented with whole white lupin (Lupinus albus $\mathrm{Cv}$. Amiga) seeds on fatty acid composition and indexes related to human health in hind leg meat and perirenal fat. Meat Sci. 87, 40-45, https://doi.org/10.1016/j.meatsci.2010.08.015

Volek Z., Marounek M., Volková L., Kudrnová E., 2014. Effect of diets containing whole white lupin seeds on rabbit doe milk yield and milk fatty acid composition as well as the growth and health of their litters. J. Anim. Sci. 92, 2041-2049, https://doi. org/10.2527/jas.2013-7120

Volek Z., Ebeid T.A., Uhliřrová L., 2018a. The impact of substituting soybean meal and sunflower meal with a mixture of white lupine seeds and rapeseed meal on rabbit doe milk yield, and composition, and the growth performance and carcass traits of their litters. Anim. Feed Sci. Technol. 236, 187-195, https:// doi.org/10.1016/j.anifeedsci.2017.12.011

Volek Z., Bureš D., Uhlírová L., 2018b. Effect of dietary dehulled white lupine seed supplementation on the growth, carcass traits and chemical, physical and sensory meat quality parameters of growing-fattening rabbits. Meat Sci. 141, 50-56, https://doi. org/10.1016/j.meatsci.2018.03.013

Xiccato G., Trocino A., 2010. Energy and protein metabolism and requirements. In: C. de Blas, J. Wiseman (Editors). Nutrition of the Rabbit. $2^{\text {nd }}$ Edition. CAB International. Wallingford (UK), pp. 83-118, https://doi.org/10.1079/9781845936693.0083

Zduńczyk Z., Juśkiewicz J., Flis M., 1996. Effect of dehulling white lupin (Lupinus albus) on protein utilization by rats. J. Anim. Feed Sci. 5, 281-288, https://doi.org/10.22358/jafs/69607/1996

Zwoliński C., Gugołek A., Strychalski J., Kowalska D., ChwastowskaSiwiecka I., Konstantynowicz M., 2017. The effect of substitution of soybean meal with a mixture of rapeseed meal, white lupin grain, and pea grain on performance indicators, nutrient digestibility, and nitrogen retention in Popielno White rabbits. J. Appl. Anim. Res. 45, 570-576, https://doi.org/10.10 80/09712119.2016.1233107 